\title{
State-Society Relations to Prevent Radicalism and Violent Extremism in the Cyberspace of Indonesia
}

\author{
Muhaimin Zulhair Achsin \\ \{muhaimin.zul@ub.ac.id\} \\ Universitas Brawijaya, Malang, Indonesia
}

\begin{abstract}
This research poses a question on how state - society/community relations work to prevent radicalism and violent extremism in the cyberspace of Indonesia through the implementation of PVE (Prevent Violent Extremism) / CVE (Countering Violent Extremism) concept, especially in regards to the importance of engagement with non-state actors. State in this research refers to the leading government agency who carries the responsibility of combating terrorism, namely BNPT (Badan Nasional Penanggulangan Terrorisme/ National Agency for Combating Terrorism). The chosen research method is qualitative descriptive, using both primary and secondary data. The primary data was obtained through interview sessions with some reliable and key informants during July and August of 2019. The results in particular show that BNPT has implemented the PVE/CVE in the top-down relations and state-driven network, but it has not been able to fully encourage the growth of civil society's collective awareness to be voluntarily active in radicalism prevention, particularly in cyberspace.
\end{abstract}

Keywords: Cyberspace, Indonesia, Prevent Radicalism, Relation, Terrorism

\section{Introduction}

This Universally agreed upon, globalization in the 21 st century has effects on technology and information. In particular, the expansion of internet infrastructures and users are correlated with the increase of terrorist campaigns to influence mass. The nature of internet that is unregulated, accessible, anonymous, and attractive has made it a grand potential market for all humankind, including terrorists to reach their audience widely, build network, mine data, recruit people, and gain funds.

Through the course of late 1990s to 2007, terrorist websites rose extremely from the mere amount of a dozen to over 5,800 [1], the number has increased up to more than 9,600 websites by October 2013. Weimann through his book in 2015 also explained that terrorists are using the internet for online recruitment, radicalization and mobilization, online fatwas, cyberattacks, online debates, narrowcasting (targeting children and women), and growing lone wolf terrorists [2].

Furthermore, ISIS, besides Al-Qaeda, is infamously known as the terrorist group that use the cyberspace systematically to spread the propaganda worldwide, war on the ground and cyberspace as cyberterrorism. They succeeded in expanding their cells worldwide despite losing the battle on the ground.

ISIS has used all kind of social networking - YouTube, Facebook, WhatsApp, Instagram, Twitter, Skype, KIK or Diaspora. ISIS also used application namely Alrawi app, Amaq News, 
The Dawn of Glad Tidings and digital magazine Dabiq. Even Google has deleted some accounts due to the popularity of the question "How to join the IS [3].

However, in Indonesia, a case study in 2016 of the first woman who became a suicide bomber, an ISIS cell, Dian Novita Yuli, depicted to the public eye how significant the influence of social media containing ISIS doctrine and network truly in turning an ordinary woman into a suicide bomber. Even though she was not the first woman involved in terrorism in Indonesia, Munfiatun Nurdin M. Top's wife was the first, Dian showed a new phenomenon namely the influence of the internet regarding women's involvement in terrorist activities in Indonesia. Khaira Dhania showed the same pattern as well. Dhania was one of the Indonesian women who became an ISIS supporter and went to Syria in 2015 to join ISIS. During the time, she was only 16 years old and had just began to learn religion through social media, particularly Facebook. She successfully persuaded her nuclear family to go to Syria together. Two years later, in 2017, Dhania and her family escaped from ISIS control and returned back to Indonesia. Since then, Dhania has been actively speaking up to the public in Indonesia about the danger of underestimating online media propaganda's impact.

To prevent similar cases repeated, government has intervened the cyberspace through the Ministry of Communication and Information or Kominfo (abbreviation in Indonesia). From 2009 to $2019,11.000$ social media contents that were spread radicalism and terrorism has been blocked by Kominfo, in which Facebook and Instagram are the two social medias that contain the most of radical and terrorism contents that mount up to 8.131 in total [4]. Therefore, this paper attempts to answer the question how do state - society/community relations to prevent radicalism and violent extremism in the cyberspace of Indonesia?

Several written works about terrorism in Indonesia have been produced such as the nature of Indonesian terrorist motive [5], Jemaah Islamiyah [6,7], democratization and terrorism in Indonesia [8], latent threat of Islamist Terrorism in Indonesia [9], ten radical groups in Indonesia [10], securitisation of terrorism in Indonesia [11], radicalization of Indonesia female supporters of IS [12], and disengagement Indonesian jihadist [13]. However, none of those works have explained about state - society relation regarding terrorism prevent effort in cyberspace of Indonesia. Therefore, this research fills that void.

\section{Research Method}

The chosen research method is qualitative descriptive, using both primary and secondary data. Primary data was collected through interview sessions with a reliable informant of BNPT officer in July 2019, a key informant of Nahdlatul Ulama and Muhammdiyah organization in July 2019, Duta Damai's member, FKPT officer, and several NGOs in August 2019. Furthermore to get more knowledge and context of the pattern, observation of the social medias and internet also became an integral part of this research. The analysis data technique is implementing what Uwe Flick [14] has said regarding classification and interpretation to produce statements about implicit and explicit dimensions, as well as structures of meaningmaking in the material and what is represented in it (technique flows: overviews, condensation, summary, categories, interpretation).

In this research, state refers to the government, and according to national law no.5/2019, specifically in the article 43 mentioned that leading agency for combating Terrorism is BNPT (Badan Nasional Penanggulangan Terrorisme/ National Agency for Combating Terrorism). 
Other government apparatus that has responsibility to control cyberspace is the Ministry of Communication and Information.

This research uses the concept of PVE (Prevent Violent Extremism)/CVE (Countering Violent Extremism). The concept of CVE established in 2015 in official political jargon of US President Barrack Obama. Moreover, at the beginning of 2016, US Secretary-General Ban Ki Moon has announced UN Plan of Action to Prevent Violent Extremism. The idea underpinning CVE is that violent extremists should not fought exclusively with intelligence, police, and military means. The structural cause of violent extremism must also be tackled including intolerance, government failure, and political, economic and social marginalization [15].

Beside reducing the structural causes, PVE/CVE also addressed the importance of engage with non-state actors. UN Security Council Resolution 2178 stated that encourage the member states to engage relevant local communities and NGOs including empowering youth, families, religious, cultural and education leaders, and all others concerned groups of civil society [16]. PVE/CVE based on soft approach, meanwhile Counter Terrorism relies on hard power approach. Therefore, civic engagement becomes more important now than ever before. This paper uses the notion of state - non-state actor engagement within PVE/CVE concept.

\section{Result and Discussion}

BNPT has three programs namely national preparedness, counter/contra radicalization, and de-radicalization. The preventive function exists on the counter radicalization program where its early step is the effort to reduce radical thought/ideology through counter/contra propaganda.

The counter propaganda runs on two tracks both of offline and online. On the offline track, BNPT maintains a good relation with civil society organizations, communities, religious leaders, indigenous leaders, and universities stakeholders through dialogues, socializations, seminars and other offline meetings.

In Indonesia, there are two major Islamic civil society organizations namely Nadhlatul Ulama (NU) and Muhammadiyah. BNPT tried to engage with these two large organizations to counter radicalization and instead to pursue de-radicalization by involving them as speakers in meeting/seminar/dialogue as well as spreading information regarding the event on social media. Despite that fact, our respondents have explained that they were rarely involved in the big design of the counter radicalization program itself. This relation seems to portray a "need-based" model, in which BNPT will utilize and activate their civil society networks mostly when in need of support for short term events.

On the online track, the BNPT strategies can be categorized into two: namely online platforms that directly BNPT made and other online networks by creating engagement with the communities or proxy. The former manifested on the website with the keywords "damai" (peace) namely jalandamai.org focusing on educative angle, and damailahindonesiaku.com focusing on informative side. On mainstream social medias Facebook, Instagram, Twitter and Youtube, BNPT created under the account or channel named "damailah RI".

For the latter strategy, since 2016 BNPT has created peace ambassador (Duta Damai in Bahasa) that targeted youth in the 13 provinces in Indonesia. Each province consists of 60 youth, mounting up 780 in total whom possess three basic skills namely information technology, visual communication design, and blogging (blogger). Furthermore, the Peace ambassador initiative has been expanded to the regional scheme of Southeast Asian nations with the purpose of 
replicating Indonesia's best practice of radicalism prevention in other countries, particularly in Southeast Asian nations.

Generally, Duta Damai is a youth community that is active on social media to post positive contents which mainly are aimed to prevent radicalism and extremism on the internet that targeted youth. Beside having a website, Duta Damai members conducted a peace campaign on social media, particularly Facebook and Instagram, that emphasized on critical thinking in hope for the audience to understand the serious risk of online media propaganda and avoid underestimation. Throughout these campaign, the challenges faced are the absence of a precise target audience, the clarity of indicators that are used to evaluate whether the program is right on target, and an innovative strategy to reach a large number of visitors on their social media campaign.

One of the rationalization behind the formation of Duta Damai in the thirteen provinces, which Indonesia actually consists of thirty four provinces, is the history of terrorism activities in those selected provinces. For example, the establishment of Duta Damai in West Nusa Tenggara province (NTB/Nusa Tenggara Barat) in 2017 was caused by the terrorist activities and networks in Bima which turned NTB province into a "red-zone". Duta Damai members are youths who have a lot of energy and time, they help developing relations with the other civil society organizations that is more fluid to prevent radicalization and extremism. Nevertheless, there are reciprocal relations between BNPT and Duta Damai members. For BNPT, this collaboration can add the amount of actors that are working on extremism prevention in cyberspace whereas Duta Damai members perceive this opportunity as a way to leverage their knowledge and personal branding in their particular society.

The former and the latter strategies are connected to the peace media center of BNPT. BNPT also creates relations with the social media influencers to spread peace message to the wider audiences. However, the way BNPT and its communities network are expressed in all cyberspace through mobilizing symbols of BNPT, beside the tolerance, moderate and peace messages.

The important influencers nowadays in the context of prevention and de-radicalization in Indonesia (both of online and offline) are ex-terrorists such as Ali Imron (Bali Bombings), Ali Fauzi (Bali Bombing), Sofyan Tsauri, etc. These former terrorists have the ability to frame argument and make the counter-argument in the contexts of extremism prevention and deradicalization. They become important influencers and actors in the cyberspace. Furthermore, BNPT sees the potentials of these actors and therefore build engagement with them to spread the campaign on prevention and de-radicalization programs.

Examining the pattern of relations, the networks are still relying on state-centric discourse and top-down mechanism. The social community's resilience through voluntary action in preventing extremism in the cyberspace is still marginal. One prime example of a counter propaganda in cyberspace that is outside of BNPT's direct circle is NU online. It is a website that is owned by the biggest Muslim organizations in Indonesia, Nahdlatul Ulama, which emphasizes on moderate Muslim thoughts. The rise of the NU online media is seen as a response against the extremist cyberspace propaganda based on their own internal dynamics. Meanwhile the internal dynamics of the Muhammadiyah organization have not yet reached a consensus on whether terrorism discourse is something natural, an actual threat, or a thing by design made by interested parties. 


\section{Conclusion}

BNPT has been present as the leading government agency for combating terrorism on all mainstream cyberspace channels by engaging with the communities. All contents are controlled by BNPT and managed collaboratively by BNPT itself and the engaged communities, including symbols mobilization. Duta Damai or Peace Ambassador is the biggest manpower created by BNPT to spread the peaceful messages in cyberspace. BNPT also engages with multiple actors to prevent extremism in cyberspace. This relation still follows the top-down pattern. In particular, BNPT has implemented the PVE/CVE concept, but it has not been able fully to encourage the growth of civil society's collective awareness in preventing radicalism. However, the critical point is finding the proper way to evaluate the programs and measure whether or not the programs are hitting the right audiences and not just a project which follows the state budget expenditure logic per se.

\section{References}

[1] G. Weimann, Terror on the Internet : the new arena, the new challenges. Washington, D.C.: United States Institute of Peace (Bristol : University Presses Marketing) (2006)

[2] G. Weimann, Terrorism in cyberspace : the next generation.

[3] C. A. Payá-Santos and J. J. Delgado-Morán.: Use of Cyberspace for Terrorist Purposes, Security and Development, J. M. Ramírez and L. A. García-Segura Eds. Cham: Springer International Publishing, pp. 197-209 (2017)

[4] R. K. Dewi.: Selama 10 Tahun, Kominfo Blokir Lebih dari 11.000 Konten RadikalismeTerorisme. https://nasional.kompas.com-lebih-dari-terorisme (2019).

[5] K. a. Ramakrishna.:Islamist Terrorism and Militancy in Indonesia : The Power of the Manichean Mindset (2015)

[6] G. Barton, Jemaah Islamiyah : radical Islamism in Indonesia (Singapore: Ridge Books in English) (2005)

[7] S. Jones.: The changing nature of Jemaah Islamiyah. Australian Journal of International Affairs, vol. 59, no. 2, pp. 169-178 (2005)

[8] N. Eschborn, J. H. Richardson, and H. Litta.Democratization and the issue of terrorism in Indonesia. (Jakarta, Indonesia: Konrad Adenauer Stiftung) (2005)

[9] W. a. Nugroho and O. d. s. Ashour.; Understanding the existence and latent threat of Islamist terrorism through a multi-dimensional analysis : the case of Republic of Indonesia," Thesis (Ph.D.), University of Exeter (2018)

[10] J. a. Jerard, P. d. s. Lehr, and J. d. s. Jerard. Terrorism in Indonesia : an examination of ten radical groups (2005)

[11] A. A. a. Wibisono.: Securitisation of terrorism in Indonesia, Thesis (Ph.D.), University of Nottingham (2015)

[12] N. Nuraniyah.: Not Just Brainwashed: Understanding the Radicalization of Indonesian Female Supporters of the Islamic State Terrorism and Political Violence, vol. 30, no. 6, pp. 890-910 (2018)

[13] J. C. Hwang, Why Terrorists Quit The Disengagement of Indonesian Jihadists. Cornell University Press (2018)

[14] U. Flick, The SAGE handbook of qualitative data analysis. (in English), 2014.

[15] C. Nünlist and O. Frazer.: The Concept of Countering Violent Extremism," CSS Analyses in Security Policy (2015)

[16] UN Security Council Resolution 2178 (2014) 